\title{
Is S-upar level correlated to the length of hospitalization
}

\author{
Esben K Baymler, Ina K Jensen, Mathias B Danielsen, Astrid J Damgaard, Kjeld A Damgaard ${ }^{*}$ \\ From 6th Danish Emergency Medicine Conference \\ Odense, Denmark. 20-21 November 2014
}

\section{Background}

The purpose of this study is to investigate, if S-uPAR correlates with expected length of patients' hospitalization. This could be useful in emergency medicine, due to the acute departments treating patients hospitalized for 48 hours or less. S-uPAR (Urokinase Plasminogen Activator, CD87) is a potential biomarker thought to be related to inflammatory immune cells activation. It is expressed on various immune cells including neutrophils, monocytes, macrophages, and lymphocytes. Upon inflammation, it is cleaved from the cell surface and released into serum. S-uPAR has shown prognostic and clinical value in the triage of patients as described in an editorial comment in the Journal of Internal Medicine 2012 [1].

\section{Methods}

It is a follow-up study including 60 unselected patients $(\mathrm{n}=$ 60 ) above 60 years of age and is the first sample of a larger study including 500 patients. Blood samples in this study have been collected from patients at admission. The samples were frozen afterwards and the patients have been examined retrospectively by physicians and stratified into groups: hospitalized $<24$ hours, 24-72 hours, and $>72$ hours.

\section{Results}

The mean S-uPAR value for the $<24$ hroup $(\mathrm{n}=14)$ was 2.75 (1.5 - 24.3). This compared to the 24-72h group ( $\mathrm{n}=$ 13) with a mean value of $4.3(3.4-16.9)$ and the $>72 \mathrm{~h}$ group $(\mathrm{n}=29)$ with a mean value of $4.1(0.8-18.7)$.

\section{Conclusion}

Patients hospitalized $<24$ h have lower S-uPAR values compared to patients hospitalized $>24 \mathrm{~h}$. Preliminary findings of the study show no correlation between the patients S-uPAR values and the length of hospitalization.

Emergency Medicine Department, Hospital of Vendsyssel, Denmark
When all 500 patients have been included, further analysis will be conducted, including analysis of patients presenting very high and very low S-uPAR values to exclude those with known confounders.

Published: 16 July 2015

\section{Reference}

1. Koch A, Tacke F: Risk stratification and triage in the emergency department: has this become 'suPAR' easy? Journal of Internal Medicine 2012, 272(3):243-246.

\section{doi:10.1186/1757-7241-23-S1-A32}

Cite this article as: Baymler et al:: Is S-upar level correlated to the length of hospitalization. Scandinavian Journal of Trauma, Resuscitation and Emergency Medicine 2015 23(Suppl 1):A32.
Submit your next manuscript to BioMed Central and take full advantage of:

- Convenient online submission

- Thorough peer review

- No space constraints or color figure charges

- Immediate publication on acceptance

- Inclusion in PubMed, CAS, Scopus and Google Scholar

- Research which is freely available for redistribution

\section{() Biomed Central}

